\title{
Synthesis and Evaluation of Water-Soluble Poly(vinyl alcohol)-paclitaxel Conjugate as a Macromolecular Prodrug
}

\author{
Atsufumi Kakinoki, Yoshiharu Kaneo, ${ }^{*}$ Tetsuro Tanaka, and Yoshitsugu HosoKawa \\ Laboratory of Biopharmaceutics, Faculty of Pharmacy and Pharmaceutical Sciences, Fukuyama University; Fukuyama, \\ Hiroshima 729-0292, Japan. Received November 18, 2007; accepted January 31, 2008
}

\begin{abstract}
Paclitaxel (PTX) is an antitumor agent for the treatment of various human cancers. Cremophor EL ${ }^{\circledR}$ and ethanol are used to formulate PTX in commercial injection solutions, because of its poor solubility in water. However, these agents cause severe allergic reaction upon intravenous administration. The aim of this study is to synthesize water-soluble macromolecular prodrugs of PTX for enhancing the therapeutic efficacy. Poly(vinyl alcohol) (PVA, $80 \mathrm{kDa}$ ), water-soluble synthetic polymer, was used as a drug carrier which is safe and stable in the body. The 2'-hydroxyl group of PTX was reacted with succinic anhydride and then carboxylic group of the succinyl spacer was coupled to PVA via ethylene diamine spacer, resulting the water-soluble prodrug of poly(vinyl alcohol)-paclitaxel conjugate (PVA-SPTX). The solubility of PTX was greatly enhanced by the conjugation to PVA. The release of PTX from the conjugate was accelerated at the neutral to basic conditions in in vitro release experiment. [ $\left.{ }^{125} \mathrm{I}\right]$-labeled PVA-SPTX was retained in the blood circulation for several days and was gradually distributed into the tumorous tissue after intravenous injection to the tumor-bearing mice. PVA-SPTX inhibited the growth of sarcoma 180 cells subcutaneously inoculated in mice. It was suggested that the water-solubility of PTX was markedly enhanced by the conjugation to PVA, and PVA-SPTX effectively delivered PTX to the tumorous tissue due to the enhanced permeability and retention (EPR) effect.
\end{abstract}

Key words poly(vinyl alcohol); paclitaxel; macromolecular prodrug; cytotoxicity; antitumor activity

Paclitaxel (PTX) is an anti-microtubule agent isolated from the trunk bark of the Pacific Yew tree, Taxus brevifolia. ${ }^{1)}$ It has been widely used as an anti-neoplastic agent for a variety of human cancers including breast, ovarian, nonsmall cell lung, head and neck cancers, leukemia, and melanoma. ${ }^{2-6)}$

PTX is a highly hydrophobic drug and is hardly soluble in water (water solubility $<0.3 \mu \mathrm{g} / \mathrm{ml}$ ). ${ }^{7}$ ) Because of its poor solubility in water and many other acceptable pharmaceutical solvents, specific emulsionizers, such as Cremophor EL ${ }^{\circledR}$, are used to formulate PTX in commercial injection solutions. However, serious hypersensitivity reactions have been reported in some individuals since the content of Cremophor $\mathrm{EL}^{\circledR}$ used in the PTX formulation is significantly higher than in any other marketed drug. ${ }^{8,9)}$ Side effects of PTX formulation include nausea and vomiting, diarrhea, mucositis, myelosuppression, cardiotoxicity and neurotoxicity. ${ }^{10,11)}$

In addition, Cremophor $\mathrm{EL}^{\circledR}$ is known to leach phthalate plasticizers from polyvinylchloride bags and intravenous tubing. ${ }^{12}$ Therefore, alternative dosage forms for the PTX administration need to be developed to reduce the undesirable side effects induced by using Cremophor EL ${ }^{\circledR}$.

In recent years the use of water-soluble polymers as drug delivery systems has been received increasing attention. $\mathrm{Li}$ et $a l .{ }^{13)}$ and Greenwald et $a l .{ }^{14)}$ reported the conjugation of polyethylene glycol (PEG) to the 2'-position of PTX through a spacer succinyl group. They demonstrated that PEG may be used as an effective solubilizing carrier for PTX. Poly-Lglutamic acid was also used to make a water-soluble PTX conjugate. ${ }^{15-17)}$ It was demonstrated that the poly-(L-glutamic acid)-paclitaxel conjugate was more effective than standard PTX. On the other hand, Sugahara et al. constructed the PTX delivery system using amino acid linkers in the conjugation of PTX with carboxymethyldextran. ${ }^{18)}$

The consequence of attachment of low molecular weight drugs to macromolecular carriers alters their rate of excretion from the body, changes their toxicity and immunogenicity, and limits their uptake by cells via endocytosis, thus providing the opportunity to direct the drug to the particular cell type where its activity is needed. ${ }^{19)}$ In addition, these macromolecular conjugates can accumulate in solid tumors due to the enhanced microvasculature of tumor tissue. ${ }^{20,21)}$ This phenomenon has been termed enhanced permeability and retention in relation to tumor targeting (EPR-phenomenon). ${ }^{22-24)}$

Poly(vinyl alcohol) (PVA) is a polymer which is synthesized by polymerizing not a vinyl alcohol monomer but a vinyl acetate monomer. This monomer is polymerized in to poly(vinyl acetate) and then hydrolyzed to produce PVA. PVA's biocompatibility makes it an excellent material for use in medical applications such as soft contact lenses. Recently, PVA has been used for long-term implants, including a bioartificial pancreas, artificial cartilage, nonadhesive film, and esophagus or scleral buckling material. ${ }^{25)}$ Furthermore, PVA has numerous functional groups which are capable of covalently coupling drug molecules.

In the previous study, we first synthesized a PVA-doxorubicin conjugate and demonstrated that PVA provides a potential targetable drug delivery system. ${ }^{26)}$ In this paper we report on the synthesis of the poly(vinyl alcohol)-paclitaxel conjugate, its release experiment, cytotoxicity, tissue distribution, and antitumor activity.

\section{MATERIALS AND METHODS}

Animals Male ddY mice at 5 weeks of age were purchased from Shimizu laboratory supplies (Shizuoka, Japan) and housed under a standard condition of temperature and light. Mice were given free access to commercial food and tap water. All animal experiments were conducted in accordance with the institutional guideline for the care and use of laboratory animals for research, which conforms to the guideline of Science Council of Japan. 
Materials Paclitaxel (PTX) was obtained from Tokyo Chemical Industry Co., Ltd., Japan. PVA (80 K, MW=80520) was kindly supplied by Japan Vam \& Poval Co., Ltd., Osaka, Japan. All other chemicals and reagents were of the highest grade commercially available. Purebright MB37-50T, a solubilizer of an amphiphilic polymer, was purchased from NOF Corporation, Tokyo.

Preparation of Poly(vinyl alcohol)-Paclitaxel Conjugate Ethylenediamine residues were introduced to the hydroxyl groups of PVA molecules by the 1,1'-carbonyldiimidazole (CDI) activation method. ${ }^{26-29)}$ Four milliliters of dimethyl sulfoxide (DMSO) containing CDI (74 mg) was added to $400 \mathrm{mg}$ of PVA dissolved in $60 \mathrm{ml}$ of DMSO, followed by stirring for $1 \mathrm{~h}$ at room temperature. After several precipitations in butanol to remove unreacted reagents, the fraction of CDI-activated PVA was dried in vacuo. Then, ethylenediamine $(2 \mathrm{~g})$ was added to the CDI-activated PVA $(200 \mathrm{mg})$ dissolved in $50 \mathrm{ml}$ of DMSO and stirred for $48 \mathrm{~h}$ at $50{ }^{\circ} \mathrm{C}$. After several precipitations in butanol to remove unreacted reagents, the fraction of PVA-ethylenediamine was dried in vacuo. The free amino groups of ethylenediamine spacers introduced into the PVA molecule were measured by the 2,4,6-trinitrobenzenesulfonic acid (TNBS) method. ${ }^{30-32)}$

2 '-Succinyl-paclitaxel (SPTX) was synthesized by the modified method of Dosio et al. ${ }^{33)}$ Briefly, PTX $(20 \mathrm{mg}$, $0.023 \mathrm{mmol}$ ) was added to succinic anhydride $(14 \mathrm{mg}, 0.14$ $\mathrm{mmol})$ in the presence of 4-dimethylamino-pyridine $(0.88$ $\mathrm{mg}, 0.0072 \mathrm{mmol})$. Then $0.4 \mathrm{ml}$ of dry pyridine was added and the solution was stirred for $3 \mathrm{~h}$ at room temperature. The SPTX was purified by chromatography on a $30 \times 2.5 \mathrm{~cm} \mathrm{SiO}$ column eluted with chloroform-methanol mixture ( $97: 3$ to $90: 10)$ as determined by TLC ( $R f 0.27$ in chloroformmethanol $90: 10)$. Its structure was confirmed by ${ }^{1} \mathrm{H}-\mathrm{NMR}$ $\left(500 \mathrm{MHz}, \mathrm{CDCl}_{3}\right) \delta: \mathrm{S} 1.13(\mathrm{~s}, 17 \mathrm{H}), 1.22(\mathrm{~s}, 16 \mathrm{H}), 1.67(\mathrm{~s}$, 19H), 1.90 (s, 18H), 2.17 (m, 14H), 2.20 (s, 4-OAc), 2.43 (s, 10-OAc), 2.57 (m, $\left.\mathrm{CH}_{2} \mathrm{CH}_{2}\right), 3.80(\mathrm{~d}, 3 \mathrm{H}), 4.19$ and $4.30(\mathrm{~d}$, 20H), 4.42 (m, 7H), 4.96 (d, 5H), $5.52\left(\mathrm{~d}, 2^{\prime} \mathrm{H}\right), 5.68(\mathrm{~d}, 2 \mathrm{H})$, $5.98\left(\mathrm{dd}, 3^{\prime} \mathrm{H}\right), 6.23(\mathrm{t}, 13 \mathrm{H}), 6.29(\mathrm{~s}, 10 \mathrm{H}), 7.10(\mathrm{~d}, \mathrm{NH})$, 7.33 (m, 3' -Ph), 7.40 (m, 3'-NBz), 7.50 (m, 2-OBz), 7.75 (d, $3^{\prime}$-NBz), 8.13 (d, 2-OBz).

The SPTX $(21.0 \mathrm{mg}, 0.022 \mathrm{mmol})$, dissolved in DMSOdimethylformamide $(70: 30)$ solution containing $N$-hydroxy3-sulfo-succinimide (sulfo-NHS, Fluka Chimica, Milan, Italy) $(9.7 \mathrm{mg}, 0.044 \mathrm{mmol})$ and 1-(3-dimethylaminopropyl)3-ethylcarbodiimide hydrochloride (EDC) $(8.6 \mathrm{mg}, 0.044$ $\mathrm{mmol})$. After $14 \mathrm{~h}$ at room temperature the reaction was complete as determined by TLC ( $R f=0.18$ in chloroformmethanol, 90:10). Then, PVA-ethylenediamine $(200 \mathrm{mg})$ dissolved in $20 \mathrm{ml}$ DMSO was added to the activatedSPTX and stirred for $48 \mathrm{~h}$ at room temperature. After several precipitations in butanol to remove unreacted reagents, the fraction of PVA-SPTX conjugate was dried in vacuo. Characterization of the conjugate was carried out using a three dimensional high-performance size exclusion chromatography described later.

PTX Content of the Conjugate The conjugate was dissolved in distilled water, and the absorbance at $227 \mathrm{~nm}$ was measured. The PTX content of the conjugates was estimated using the calibration curve of PTX standard.

In Vitro Release Experiment The release of PTX from the conjugate was determined in a $0.05 \mathrm{M}$ phosphate buffer system ( $\mathrm{pH} 4.0,5.0,6.0,7.0,8.0$ and 9.0, $\mu=0.15)$ containing $1.5 \mathrm{M} \mathrm{N}, N$-diethylnicotinamide (DENA) at $37^{\circ} \mathrm{C}$. The experiment was initiated by the addition of the stock solution to a preheated buffer solution to give a concentration of 0.25 $\mathrm{mg} / \mathrm{ml}$ of PVA-SPTX conjugate, respectively. At a fixed time intervals, the amount of PTX released was determined by using a HPLC method described later.

In Vitro Cytotoxicity Mouse leukemia L1210 was kindly provided by Institute of Development, Aging and Cancer, Tohoku University (Miyagi, Japan). Cells were typically kept in continuous logarithmic growth at $37^{\circ} \mathrm{C}$ in a humidified atmosphere in 5\% $\mathrm{CO}_{2}-95 \%$ air in RPMI 1640 medium (Nacalai, Kyoto, Japan), supplemented with $10 \%$ heat-inactivated fetal bovine serum (FBS) (Gibco, Tokyo, Japan) and $50 \mathrm{U} / \mathrm{ml}$ penicillin and $50 \mu \mathrm{g} / \mathrm{ml}$ streptomycin (Dainippon Sumitomo Pharma Co., Ltd., Tokyo, Japan). The number of viable cells was determined by the trypan blue exclusion method by using a Burker-Turk hematocytometer 3 $\mathrm{d}$ after incubation.

PVA-SPTX and PTX in Purebright MB37-50T were dissolved in RPMI1640 medium. PTX was dissolved in DMSO, then diluted by the tissue culture medium. The solutions of each sample were added to test wells to a final volume of $200 \mu \mathrm{l} /$ well in 96 -well plates. Cells were seeded into the plates at a density of $0.5 \times 10^{4}$ cells $/ 200 \mu \mathrm{l} /$ well. Plates were incubated at $37^{\circ} \mathrm{C}$ for $3 \mathrm{~d}$. Subsequently, cellular proliferation was examined by an additional incubation for $3 \mathrm{~h}$ with Alamar Blue (Kanto Reagents, Tokyo, Japan). ${ }^{34)}$ Cellular proliferation induces a chemical reduction of the Alamar Blue which results in a change in redox color from blue to red. The proliferation of cultures with Alamar Blue was determined by measuring absorbance at $570 \mathrm{~nm}$ and $600 \mathrm{~nm}$ in an immuno plate reader (NJ-2300, Inter Med Japan, Tokyo, Japan). Growth inhibition (\%) was calculated as follows.

growth inhibition $(\%)=(1-(\mathrm{T}-\mathrm{B}) /(\mathrm{C}-\mathrm{B})) \times 100$

where $\mathrm{T}, \mathrm{B}$, and $\mathrm{C}$ represent the scaled difference in absorbance at $570 \mathrm{~nm}$ and $600 \mathrm{~nm}$ of the test compound, the blank and the control, respectively.

Preparation of $\left[{ }^{125} \mathrm{I}\right]$-Labeled PVA-SPTX $\left(\left[{ }^{125} \mathrm{I}\right]-\mathrm{PVA}-\mathrm{S}\right.$ PTX) PVA-SPTX $(200 \mu \mathrm{g})$ was labeled with $0.25 \mathrm{mCi}$ of $\left[{ }^{125} \mathrm{I}\right]$ iodine by using Bolton and Hunter reagent for protein iodination (GE Healthcare Bio-Sciences, Tokyo, Japan). Unreacted $\left[{ }^{125} \mathrm{I}\right]$ was removed by chromatography on a PD-10 column (Amersham Pharmacia Biotech).

Tissue Distribution in Tumor-Bearing Mice S180 cells $\left(1 \times 10^{6}\right.$ cells/mouse $)$ were inoculated into the subcutaneous tissue of the axillary region of ddY mice. Fourteen days after the inoculation, mice were injected with $\left[{ }^{125} \mathrm{I}\right]-\mathrm{PVA}-\mathrm{SPTX}$ $(6 \mathrm{mg} / \mathrm{kg})$ in $0.2 \mathrm{ml}$ of saline through the tail vein. Aliquots of the sample solution were stored for the calibration of the disintegration of radioiodine. At appropriate times after the administration, blood was collected from the vena cava under ether anesthesia and the tumor tissue, liver, spleen, kidney, lung, and heart were excised and weighed. The radioactivity was determined with a gamma counter (Aloka 301).

In Vivo Antitumor Activity S180 cells $\left(1 \times 10^{6}\right.$ cells/ mouse) were inoculated into the subcutaneous tissue of the axillary region of ddY mice. PVA-SPTX $(25 \mathrm{mg} / \mathrm{kg}$ in PTX equivalents) or PTX $(25 \mathrm{mg} / \mathrm{kg})$ was given as intermittent 
intravenous injections on days 7, 10, 14, 17 and 21 after tumor inoculation. Saline was used as a negative control. Tumor sizes were measured with calipers, and the tumor volumes (V) were calcualted as: $\mathrm{V}=\mathrm{L} \times \mathrm{W}^{2} / 2$, where $\mathrm{L}$ and $\mathrm{W}$ are length $(\mathrm{mm})$ and width $(\mathrm{mm})$, respectively.

Analytical Methods The amount of PTX was determined by HPLC. Chromatography was carried out using a Shimadzu liquid chromatographic system (LC-6A, Kyoto, Japan) with a variable-wavelength UV detector (SPD-6A, Shimadzu) operated at $227 \mathrm{~nm}$. A $4.6 \times 150 \mathrm{~mm}, 5-\mu \mathrm{m}$ particle size, $\mathrm{C}_{18}$ reversed-phase column (TSK gel ODS-80TM, Tosho, Japan) was used at ambient temperature. The mobile phase was a mixture of acetonitrile and $2 \mathrm{~mm}$ phosphoric acid $(55: 45, \mathrm{v} / \mathrm{v})$. The injection volume was $20 \mu \mathrm{l}$, and the flow rate was $1.0 \mathrm{ml} / \mathrm{min}$. For every experimental sample the content of PTX was calculated by measuring the relevant peak area and calibrating against the corresponding peak area derived from the $n$-hexyl $p$-hydroxybenzoate internal standard.

Three dimensional high-performance size-exclusion chromatography was carried out using a Shimadzu liquid chromatographic system (LC-9A, Kyoto, Japan) equipped with a variable-wavelength UV detector (MCPD-3600, Otsuka, Osaka, Japan). A $7.8 \times 300 \mathrm{~mm}$, TSKge1 G4000PWXL column (Tosoh) was used at $40^{\circ} \mathrm{C}$. The mobile phase was $20 \%$ acetonitrile in $50 \mathrm{~mm} \mathrm{LiCl}$. The injection volume was $50 \mu \mathrm{l}$, and the flow rate was $1.0 \mathrm{ml} / \mathrm{min}$.

\section{RESULTS}

Preparation of PVA-SPTX Conjugate PTX was bound to PVA according to the synthetic scheme shown in Fig. 1. The overall synthetic pathway involved three steps. The first was the preparation of PVA-ethylenediamine, the second the preparation of SPTX and the third the binding of SPTX and PVA-ethylenediamine.

Hydroxyl group of PVA was activated by CDI. Then, a $10-$ fold weight excess of ethylenediamine was reacted with CDIactivated PVA. An excess of the ethylenediamine was used in order to prevent crosslinking and cyclisation of the PVA chains. The number of free amino groups of the PVA-ethylenediamine was estimated by the TNBS method. ${ }^{30-32)}$ One mole of PVA showed the color intensity of $25 \mathrm{~mol}$ of free amino group.

SPTX was synthesized by the modified method of Dosio et $a l^{33)}$ The crude SPTX was purified by chromatography on a $\mathrm{SiO}_{2}$ column. It was confirmed by the ${ }^{1} \mathrm{H}-\mathrm{NMR}$ analysis that the hydroxyl group of $2^{\prime}$ position of PTX was reacted with succinic anhydride. The yield of SPTX was $94.0 \%$.

Free carboxylic group of SPTX molecule was activated with twice molar of EDC and sufo-NHS, and then reacted with PVA-ethylenediamine. The yield of PVA-SPTX was $91.4 \%$. The PTX content of the conjugates estimated by the UV method was $6.2 \mathrm{w} / \mathrm{w} \%$, corresponding to $5.8 \mathrm{~mol}$ of $\mathrm{PTX} / \mathrm{mol}$ of PVA.

Size-exclusion chromatography of the conjugate was performed by HPLC on an TSK gel G4000PWXL column. Elution peaks were detected by a photodiode array detector. The retention time of the peak top of PVA-SPTX was $8.4 \mathrm{~min}$ in the cross section at $227 \mathrm{~nm}$ (Fig. 2). PVA-SPTX eluted at the same retention time to the original PVA detected by a differential refractometer.

Kinetics of Regeneration of PTX from the Conjugate The degradation of PTX was investigated in citrate and phosphate buffer solutions containing $1.5 \mathrm{~m}$ DENA over the $\mathrm{pH}$
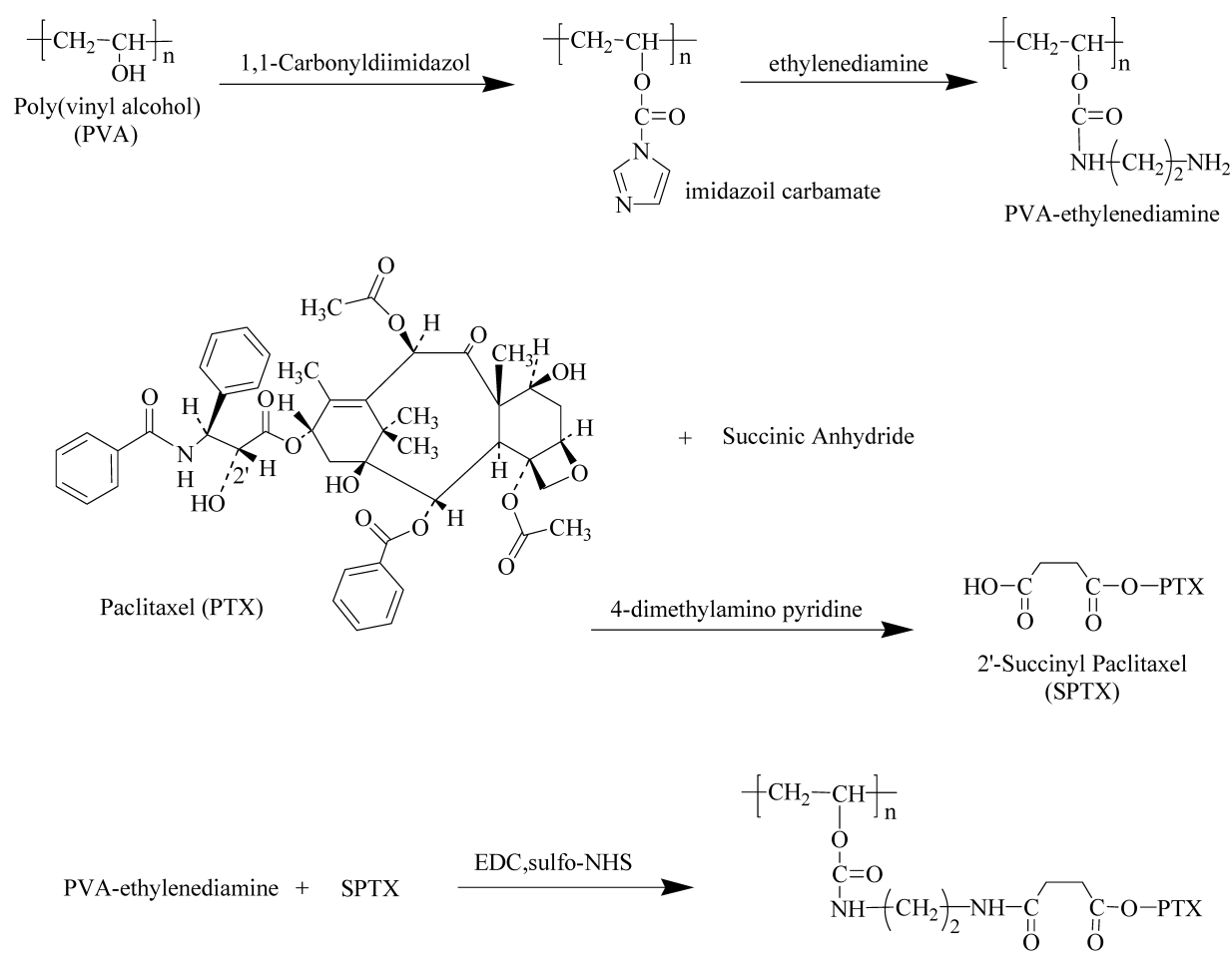

Poly(vinyl alcohol)-paclitaxel conjugate (PVA-SPTX)

Fig. 1. Synthetic Pathway of PVA-SPTX Conjugate

EDC: 1-(3-dimethylaminopropyl)3-ethylcarbodiimide hydrochloride, sulfo-NHS: $N$-hydroxy-3-sulfo-succinimide. 


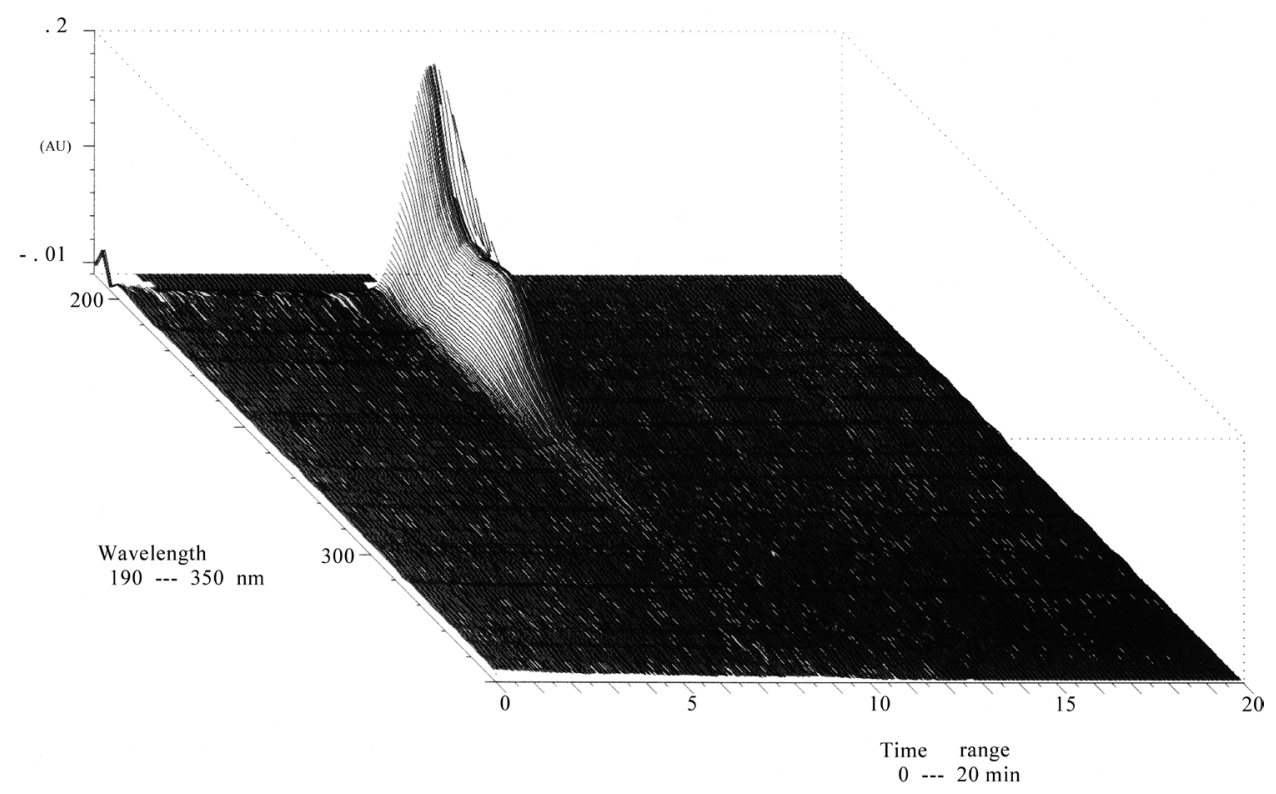

Fig. 2. Three Dimensional Chromatogram of PVA-SPTX

The retention time of the peak top of PVA-SPTX was $8.4 \mathrm{~min}$ in the cross section at $227 \mathrm{~nm}$. High-performance size-exclusion chromatography was carried out using a HPLC system equipped with a photodiode array detector. A $7.8 \times 300 \mathrm{~mm}$, TSKge1 G4000PWXL column was used at $40{ }^{\circ} \mathrm{C}$. The mobile phase was $20 \%$ acetonitrile in $50 \mathrm{~mm} \mathrm{LiCl}$ and the flow rate was $1.0 \mathrm{ml} / \mathrm{min}$

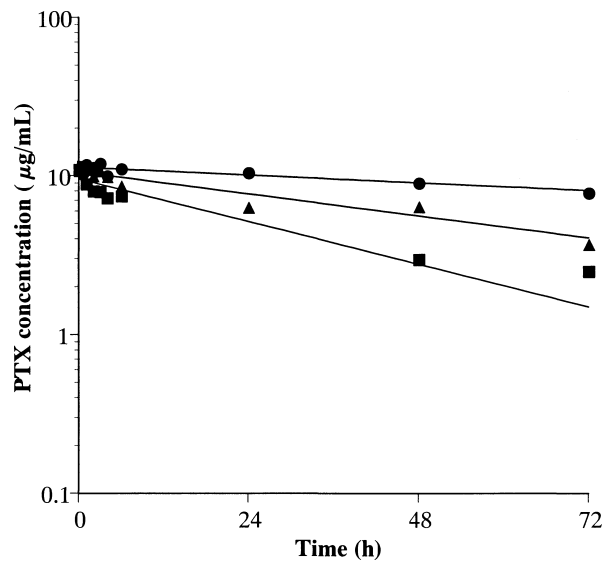

Fig. 3. Stability of PTX in $0.05 \mathrm{~m}$ Phosphate Buffer Solutions $(\mu=0.15)$ Containing $1.5 \mathrm{M}$ DENA of $\mathrm{pH} 7.0(\mathbf{O}), \mathrm{pH} 8.0(\mathbf{\Delta})$ and $\mathrm{pH} 9.0(\mathbf{\square})$ at $37^{\circ} \mathrm{C}$

range $4-9$ at $37^{\circ} \mathrm{C}$. At $\mathrm{pH} 7-9$ the degradation of PTX followed pseudo first-order kinetics as shown in Fig. 3, whereas PTX was quite stable at acidic conditions ( $\mathrm{pH} 4-6)$. Time courses for PTX regenerated after incubation of PVA-SPTX in the buffer solutions are shown in Fig. 4. The apparent firstorder rate constants for regeneration of PTX from PVA$\operatorname{SPTX}\left(k_{1}\right)$ and for decomposition of PTX $\left(k_{2}\right)$ were estimated by the curve fitting using a nonlinear least squares program $(\text { MULTI })^{35)}$ and are depicted in Fig. 5. The profiles of $k_{1}$ and $k_{2}$ showed $\mathrm{pH}$-dependency in the investigated $\mathrm{pH}$ range.

In Vitro Cytotoxicity In vitro biological efficacy of the soluble PVA-SPTX was tested using murine leukemia cell line L1210. The cytotoxicities of PVA-SPTX and PTX are shown in Fig. 6. As is evident, the cytotoxic effect of these compounds on L1210 cells was concentration dependent. PTX in DMSO showed the highest activity, whereas both PVA-SPTX and PTX in Purebright MB37-50T exhibited similar activity to that of the positive control of doxorubicin.

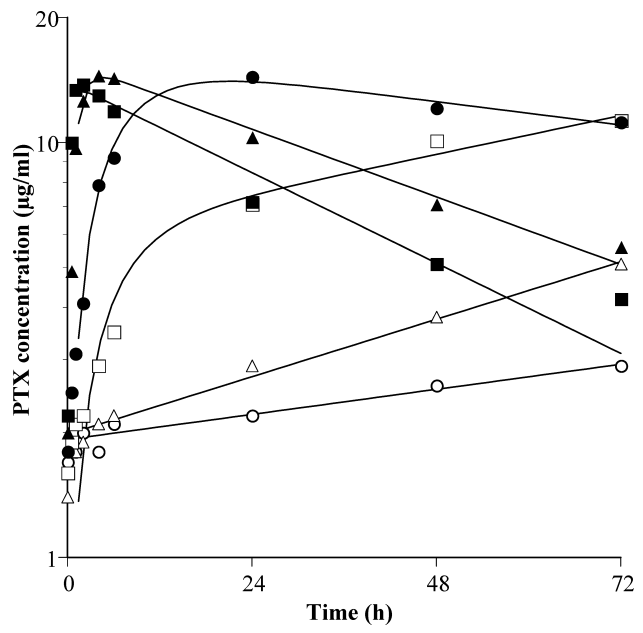

Fig. 4. Regeneration of PTX from PVA-SPTX in $0.05 \mathrm{M}$ Citrate Buffer Solutions $(\mu=0.15)$ of $\mathrm{pH} 4.0(\bigcirc), 5.0(\triangle)$ or $6.0(\square)$ and in $0.05 \mathrm{~m}$ Phosphate Buffer Solutions $(\mu=0.15)$ of $\mathrm{pH} 7.0(\mathbf{O}), 8.0(\mathbf{\Delta})$ or $9.0(\boldsymbol{\square})$ Containing $1.5 \mathrm{M}$ DENA at $37^{\circ} \mathrm{C}$

The concentration of PVA-SPTX to produce a 50\% inhibition of normal cell growth $\left(\mathrm{IC}_{50}\right)$ was $13.8 \mathrm{ng} / \mathrm{ml}$ (equivalent to PTX), whereas the $\mathrm{IC}_{50}$ of PTX in DMSO was $3.0 \mathrm{ng} / \mathrm{ml}$.

Tissue Distribution in Tumor-Bearing Mice Mice were injected with $\left[{ }^{125} \mathrm{I}\right]-\mathrm{PVA}-\mathrm{SPTX}(6 \mathrm{mg} / \mathrm{kg})$. At appropriate times until $7 \mathrm{~d}$, the radioactivities in a variety of organs were determined with a gamma counter. Figure 7 shows the time profile of the tissue distribution of $\left[{ }^{125} \mathrm{I}\right]-\mathrm{PVA}-\mathrm{SPTX}$ after intravenous injection to mice. It was found that $\left[{ }^{125} \mathrm{I}\right]-$ PVA-SPTX was retained in the blood circulation for several days and was gradually distributed into the tumorous tissue.

In Vivo Antitumor Activity Figure 8 shows the growth inhibition curves against S180 subcutaneously inoculated in mice. To determine the effect of these drugs on S180 tumor growth, PVA-SPTX $(25 \mathrm{mg} / \mathrm{kg}$ in PTX equivalents) or PTX $(25 \mathrm{mg} / \mathrm{kg})$ was given as intermittent intravenous injections 


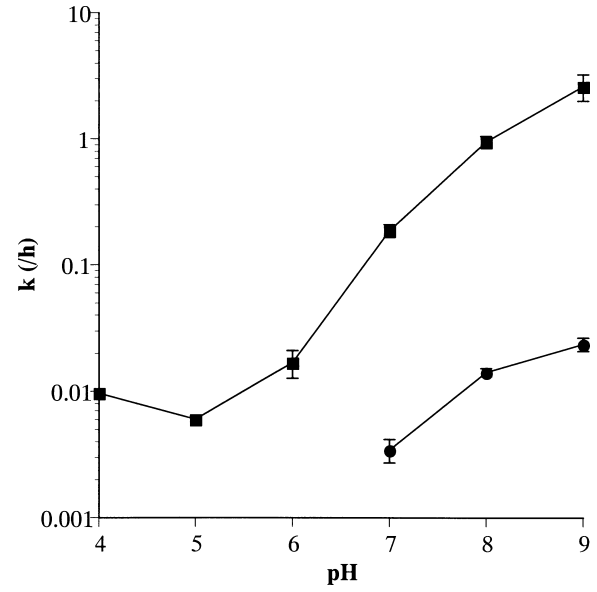

Fig. 5. $\mathrm{pH}$ Profile of Regeneration Rate Constant of PTX from PVA-SPTX (ם) and Decomposition Rate Constant of PTX $(\bullet)$ in $0.05 \mathrm{~m}$ Citrate Buffer Solutions $(\mu=0.15)$ or Phosphate Buffer Solutions $(\mu=0.15)$ Containing $1.5 \mathrm{M}$ DENA at $37^{\circ} \mathrm{C}$

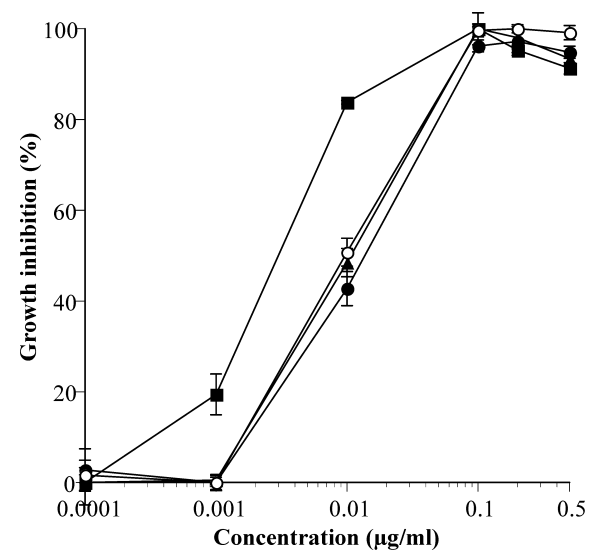

Fig. 6. Cytotoxicity of PVA-SPTX, PTX, and Doxorubicin against L1210 Cells

L1210 cells were cultivated in the medium containing each compound for $3 \mathrm{~d}$, and the cells viability was determined by the alamar blue method. $\bullet$, PVA-SPTX; $\boldsymbol{\Lambda}$, PTX (dissolved in Purebright MB37-50T solution); $\mathbf{0}$, PTX (dissolved in DMSO); O, doxorubicin. Values are given as means \pm S.D. of three experiments.

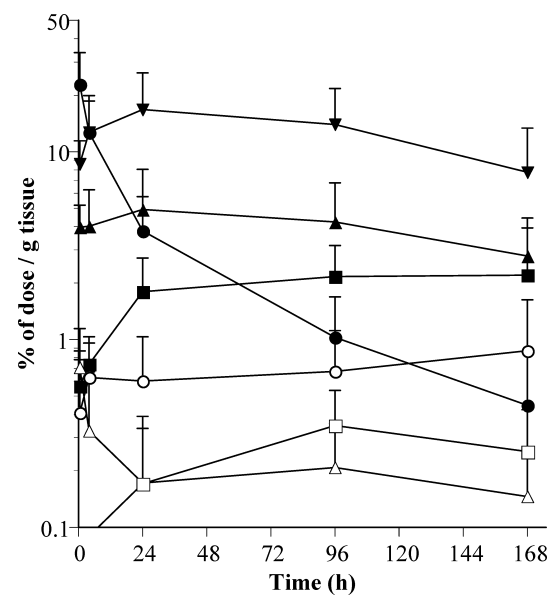

Fig. 7. Time Profile of Tissue Distribution of ${ }^{125}$ I-PVA-SPTX after Intravenous Injection $(6 \mathrm{mg} / \mathrm{kg})$ to Mice

○, plasma; $\boldsymbol{\Delta}$, liver; $\boldsymbol{\nabla}$, kidney; $\mathbf{\square}$, tumor; $\bigcirc$, spleen; $\triangle$, lung; $\square$, heart. Each point represents the mean \pm S.D. of three mice.

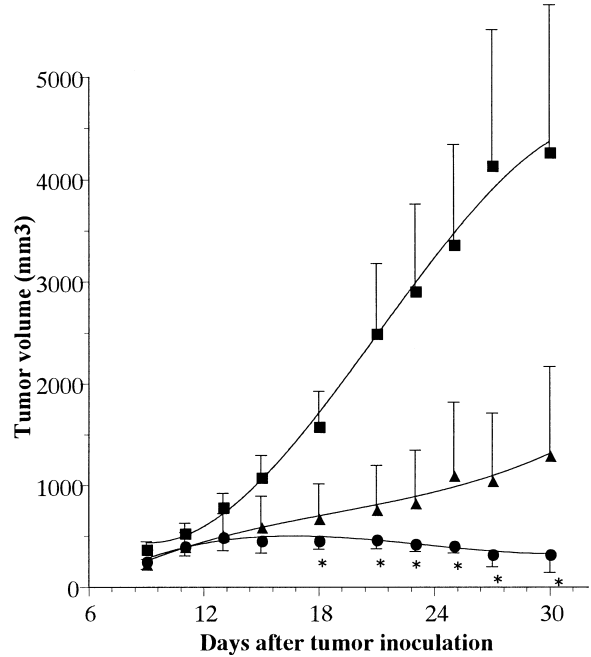

Fig. 8. Antitumor Effect of PVA-SPTX and PTX on Implanted S180 Tumor

Mice were inoculated with $\mathrm{S} 180$ cells $\left(1 \times 10^{6}\right.$ cells/mouse $)$ subcutaneously. PVA-SPTX and free PTX were given as intermittent intravenous injections on days 7 , $10,14,17$ and 21 after the tumor inoculation. - PVA-SPTX $(25 \mathrm{mg} / \mathrm{kg}$ in PTX equivalents); $\boldsymbol{\Delta}$, PTX $(25 \mathrm{mg} / \mathrm{kg}) ; \boldsymbol{\square}$, control (5\% glucose). Each point represents the mean \pm S.E. of six mice. Student's $t$-test was performed between control and PVASPTX, $* p<0.05$.

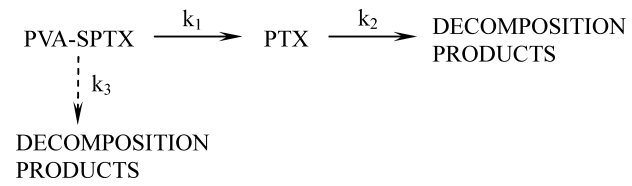

Chart 1

on days 7, 10, 14, 17 and 21 after tumor inoculation. PVASPTX caused significant tumor growth inhibition compared to the control. The control group of mice showed a progressive increase in tumor growth with the mean tumor volume increasing to $4278 \pm 1426 \mathrm{~mm}^{3}$ on day 30 after tumor inoculation. The mice treated with PVA-SPTX showed significant tumor growth inhibition (mean tumor volume 329 \pm 187 $\mathrm{mm}^{3}$ ) compared to the control group, which was almost similar to or less than the PTX-treated group (mean tumor volume $1304 \pm 864 \mathrm{~mm}^{3}$ ). In this experiment, although both PTX and PVA-SPTX did not cause the side effect of body weight loss at $25 \mathrm{mg} / \mathrm{kg}$ in PTX equivalents, the macromolecular prodrug was expected to show the tolerability at the higher dose.

\section{DISCUSSION}

The kinetics of regeneration of PTX from the conjugate was examined in citrate and phosphate buffer solutions containing $1.5 \mathrm{~m}$ DENA over the $\mathrm{pH}$ range $4-9$ at $37^{\circ} \mathrm{C}$. Since the degradation of PTX followed pseudo first-order kinetics, the overall reactions were described by Chart 1 , where $k_{1}, k_{2}$ and $k_{3}$ are apparent first-order rate constants for the depicted reactions.

Then the concentration of PTX ([PTX]) has a time dependence given by the following equation:

$$
[\mathrm{PTX}]=k_{1}[\mathrm{PTX}]^{*} /\left(k_{2}-\left(k_{1}+k_{3}\right)\right) \times\left(\exp \left(-\left(k_{1}+k_{3}\right) \mathrm{t}\right)-\exp \left(-k_{2} t\right)\right)
$$

where $[\mathrm{PTX}]^{*}$ is the initial concentration of PTX covalently 
bound to PVA-SPTX. On the other hand, the stability of PTX is expressed by the following equation:

$$
[\mathrm{PTX}]=[\mathrm{PTX}]_{0} \exp \left(-k_{2} t\right)
$$

where $[\mathrm{PTX}]_{0}$ is the initial concentration of PTX. At first the parameters of $k_{2}$ were calculated from the observed time courses shown in Fig. 3 using Eq. 2. Equation 1 was then fitted to the observed time courses shown in Fig. 4 using a nonlinear least squares program (MULTI). ${ }^{35)}$

The model suggested in Chart 1 suffered the divergence in most of the computations; even if it was converged, the negative value of $k_{3}$ with an extraordinarily large standard deviation was obtained. When it was assumed that the degradationof PTX bound to PVA is negligible, however, the excellent convergence could be obtained in the curve fitting using the algorithm of Gauss-Newton method where the following equation was adopted instead of Eq. 1.

$$
[\mathrm{PTX}]=k_{1}[\mathrm{PTX}]^{*} /\left(k_{2}-k_{1}\right) \times\left(\exp \left(-k_{1} t\right)-\exp \left(-k_{2} t\right)\right)
$$

The apparent first-order rate constants for regeneration of PTX from PVA-SPTX $\left(k_{1}\right)$ and for decomposition of PTX $\left(k_{2}\right)$ are depicted in Fig. 5. The profiles of $k_{1}$ and $k_{2}$ showed $\mathrm{pH}$-dependency in the investigated $\mathrm{pH}$ range. PTX was very stable at acidic conditions, but the decomposition was increased with the elevation of the $\mathrm{pH}$. It was reported that PTX was susceptible to mild basic hydrolysis which resulted in the formation of baccatin III as the major product. ${ }^{36)}$ The regeneration rate of PTX was also enhanced with the rise in $\mathrm{pH}$ and reached a maximum at $\mathrm{pH} 9$. At $\mathrm{pH} 7$, the regeneration of PTX $\left(k_{1}=0.187 \mathrm{~h}^{-1}\right)$ was 54-times faster than the degradation of PTX $\left(k_{2}=0.00345 \mathrm{~h}^{-1}\right)$, showing half-lives of 3.7 and $201 \mathrm{~h}$, respectively. These findings indicate that covalent binding to PVA stabilizes PTX $\left(k_{3}=0\right)$ and the macromolecular prodrug, PVA-SPTX, releases PTX gradually at physiological conditions.

In addition, the amount of PTX covalently bound to PVA-SPTX was estimated by the value of [PTX]*, which was similar to that measured by the UV method. These findings indicated that approximately $100 \%$ of PTX was released from the conjugate.

In the in vitro release experiment, we observed that PTX released from the conjugate was precipitated as a white powder in buffer solutions. Consequently $1.5 \mathrm{~m}$ DENA was added to the release medium providing a chemical sink condition for the release of PTX from PVA-SPTX. Baek et al. reported that the PTX released from poly(lactic-co-glycol acid) (PLGA) matrices was much faster in DENA solution than in serum or phosphate buffer solution. They suggested that the presence of DENA in the release medium increased the hydrolysis rate of PLGA polymers. ${ }^{37)}$ However, in this study the regeneration rate of PTX from PVA-SPTX was not accelerated in $1.5 \mathrm{M}$ DENA, being similar to those obtained in the ordinary buffer solutions, because PVA was stable in the $1.5 \mathrm{~m}$ DENA solution (data are not shown).

The in vitro cytotoxicity of PVA-SPTX was evaluated by using L1210 cells. PTX previously dissolved in a small amount of DMSO was a little more effective than the other compounds. Furthermore, one of the amphiphilic 2methacryloxyethyl phosphorylcholine (MPC) polymers, Purebright MB37-50T, was also used as the solubilizer of PTX. It was reported that Purebright MB37-50T dissolved
PTX as forming a polymeric lipid nanosphere. ${ }^{38)}$ As shown in Fig. 6, PVA-SPTX inhibited the proliferation of L1210 cells to the same extent as PTX dissolved in the Purebright MB37-50T. The cytotoxicity of PTX in the Purebright MB37-50T was similar to that reported by Wada et al. ${ }^{39)}$

In the previous work, we examined the pharmacokinetics and biodisposition of PVA in experimental animals. $\left[{ }^{125} \mathrm{I}\right]$ labeled PVA was retained in the blood circulation for several days after intravenous injection to mice. Although the tissue distribution of PVA was small, a significant accumulation in the liver, kidney and spleen was observed. ${ }^{27)}$ In this study, $\left[{ }^{125} \mathrm{I}\right]-\mathrm{PVA}-\mathrm{SPTX}$ was also retained in the blood circulation very well and was gradually accumulated in the tumorous tissue as shown in Fig. 7. These findings indicated that PVASPTX was accumulated efficiently in the tumorous tissue by EPR effect. ${ }^{22-24)}$

In conclusion, in this study the conjugate was generated from the combination of PVA and PTX for the first time. It was suggested that the water-solubility of PTX was markedly enhanced by the conjugation to PVA, and the conjugate, PVA-SPTX, effectively delivered PTX to the tumorous tissue due to the EPR effect. These studies demonstrated that PVA may be used as an effective solubilizing carrier for PTX.

Acknowledgements This work was supported in part by Grants in Aid (No. 13672406) for Scientific Research (C) from the Ministry of Education, Culture, Sports, Science and Technology, Japan (to YK). The authors are also grateful to Mr. Hiroshi Noguchi of Japan Vam \& Poval Co., Ltd., Osaka, Japan for the gift of the PVA samples. The authors particularly acknowledge T. Sunagari and D. Ishii for their technical assistance.

\section{REFERENCES}

1) Wani M. C., Taylor H. L., Wall M. E., Coggon P., McPhail A. T., J. Am. Chem. Soc., 93, 2325-2327 (1971).

2) Arbuck S. G., Christian M. C., Fisherman J. S., Cazenave L. A., Sarosy G., Suffness M., Adams J., Canetta R., Cole K. E., Friedman M. A., J. Natl. Cancer Inst. Monogr., 15, 11-24 (1993).

3) Cahan M. A., Walter K. A., Colvin O. M., Brem H., Cancer Chemother: Pharmacol., 33, 441-444 (1994).

4) Foa R., Norton L., Seidman A. D., Int. J. Clin. Lab. Res., 24, 6-14 (1994).

5) Long H. J., Mayo Clin. Proc., 69, 341-345 (1994).

6) Wiernik P. H., Einzig A. I., J. Natl. Cancer Inst. Monogr., 15, 185 187 (1993).

7) Lee J., Lee S. C., Acharya G., Chang C. J., Park K., Pharm. Res., 20, $1022-1030$ (2003).

8) Fjallskog M. L., Frii L., Bergh J., Lancet, 342, 8873-8875 (1993)

9) Panchagnula R., Int. J. Pharm., 172, 1-15 (1998).

10) Einzig A. I., Wiernik P. H., Sasloff J., Runowicz C. D., Goldberg G. L., J. Clin. Oncol., 10, 1748-1753 (1992).

11) Rogers B. B., Oncol. Nurs. Forum, 20, 1483-1489 (1993).

12) Goldspiel B. R., Ann. Pharmacother, 28, S23 - S26 (1994).

13) Li C., Yu D., Inoue T., Yang D. J., Milas L., Hunter N. R., Kim E. E., Wallace S., Anticancer Drugs, 7, 642-648 (1996).

14) Greenwald R. B., Gilbert C. W., Pendri A., Conover C. D., Xia J., Martinez A., J. Med. Chem., 39, 424-431 (1996).

15) Li C., Price J. E., Milas L., Hunter N. R., Ke S., Yu D. F., Charnsangavej C., Wallace S., Clin. Cancer Res., 5, 891-897 (1999).

16) Li C., Yu D. F., Newman R. A., Cabral F., Stephens L. C., Hunter N., Milas L., Wallace S., Cancer Res., 58, 2404-2409 (1998).

17) Singer J. W., Baker B., De Vries P., Kumar A., Shaffer S., Vawter E., Bolton M., Garzone P., Adv. Exp. Med. Biol., 519, 81-99 (2003). 
18) Sugahara S., Kajiki M., Kuriyama H., Kobayashi T. R., Biol. Pharm. Bull., 25, 632-641 (2002).

19) Ringsdorf H., J. Polym. Sci. Polym. Symp., 51, 135-153 (1975).

20) Seymour L. W., Crit. Rev. Ther. Drug Carrier Syst., 9, 135-187 (1992).

21) Yuan F., Dellian M., Fukumura D., Leunig M., Berk D. A., Torchilin V. P., Jain R. K., Cancer Res., 55, 3752-3756 (1995).

22) Maeda H., Adv. Enzyme Regul., 41, 189-207 (2001).

23) Maeda H., Wu J., Sawa T., Matsumura Y., Hori K., J. Controlled Release, 65, 271-284 (2000).

24) Maeda H., Matsumura Y., Crit. Rev. Ther. Drug Carrier Syst., 6, $193-$ 210 (1989).

25) Mallapragada S. K., McCarthy-Schroeder S., "Handbook of Pharmaceutical Controlled Release Technology," Marcel Dekker, New York, 2000, pp. 31-46.

26) Kakinoki A., Kaneo Y., Ikeda Y., Tanaka T., Fujita K., Biol. Pharm. Bull., 31, 103-110 (2008).

27) Kaneo Y., Hashihama S., Kakinoki A., Tanaka T., Nakano T., Ikeda Y., Drug Metab. Pharmacokinet., 20, 435-442 (2005).
28) Hearn M. T., Methods Enzymol., 135, 102-117 (1987).

29) Beauchamp C. O., Gonias S. L., Menapace D. P., Pizzo S. V., Anal. Biochem., 131, 25-33 (1983).

30) Habeeb A. F., Anal. Biochem., 14, 328-336 (1966).

31) Fields R., Biochem. J., 124, 581—590 (1971)

32) Fields R., Methods Enzymol., 25, 464-468 (1972).

33) Dosio F., Brusa P., Crosasso P., Arpicco S., Cattel L., J. Controlled Release, 47, 293-304 (1997).

34) de Fries R., Mitsuhashi M., J. Clin. Lab. Anal., 9, 89-95 (1995).

35) Yamaoka K., Tanigawara Y., Nakagawa T., Uno T., J. PharmacobioDyn., 4, 879-885 (1981).

36) Ringel I., Horwitz S. B., J. Pharmacol. Exp. Ther, 242, 692-698 (1987).

37) Baek N., Lee J., Park K., J. Biomater. Sci. Polym. Ed., 15, 527-542 (2004).

38) Konno T., Watanabe J., Ishihara K., J. Biomed. Mater. Res. A, 65, $209-214$ (2003).

39) Wada M., Jinno H., Ueda M., Ikeda T., Kitajima M., Konno T., Watanabe J., Ishihara K., Anticancer Res., 27, 1431-1435 (2007). 